\title{
Pengembangan Instrumen Sikap Ilmiah Untuk Siswa Sekolah Dasar
}

\author{
Dewa Nyoman Sudana ${ }^{1 *}$, Komang Sudarma ${ }^{2}$
}

1,2Jurusan Pendidikan Guru Sekolah Dasar (PGSD), Universitas Pendidikan Ganesha, Singaraja, Indonesia.

\author{
A R T I C L E I N F O \\ Article history: \\ Received 20 February 2018 \\ Received in revised form \\ 06 March 2018 \\ Accepted 19 April 2018 \\ Available online 208 May \\ 2018 \\ Kata Kunci: \\ pengembangan, sikap \\ ilmiah, sekolah dasar \\ Keywords: \\ development,scientificattitu \\ de,elementaryschool
}

\begin{abstract}
A B S T R A K
Tujuan penelitian ini adalah untuk mengetahui: (1) tahapantahapan pengembangan instrumen sikap ilmiah untuk siswa sekolah dasar. (2) kualitas instrumen sikap ilmiah yang dikembangkan dilihat dari sisi validitas, realibilitas, serta validitas konstruknya. Metode pengumpulan data menggunakan angket dengan jumlah responden sebanyak 200 siswa SD dari kelas IV sampai kelas VI. Teknik analisis data menggunakan analisis statistik dengan berbantuan Program SPPS 13 for Windows. Dilihat dari sisi kualitas instrumen yang dikembangkan terlihat realibitas instrumen kategori cukup baik sebesar 0,881 dan setelah item instrumen tereliminasi dari 36 soal menjadi 15 juga masih dalam kategori bagus yaitu 0,813 . Berdasarkan ekstraksi faktor dengan kriteria komunalitas dan rotasi faktor diperoleh 4 faktor, Jumlah faktor yang terekstrak sebanyak 4 faktor dengan persen kumulatif varian lebih besar dari $60 \%$ yaitu $65,834 \%$. Dilihat dari Validasi faktor yang dilakukan dengan membagi jumlah responden menjadi dua kelompok belahan, kemudian dilakukan analisis faktor terhadap masing-masing belahan responden. Hasil validasi faktor memperlihatkan bahwa hasil yang valid, masing-masing tetap menghasilkan 4 faktor dengan sebaran item hampir sama. ini lebih menguatkan bahwa 4 faktor dalam dimensi
\end{abstract} sikap ilmiah untuk anak SD pada instrumen yang telah kembangkan sudah cukup kuat validitas konstruknya. Hasil pengembangan instrumen sikap ilmiah sudah mencerminkan proses dan hasil yang layak digunakan untuk mengukur sikap ilmiah siswa di SD.

\section{A B S T R A C T}

The purpose of this study was to determine: (1) the stages of development of scientific attitude instruments for elementary school students. (2) the quality of the instruments developed scientific attitude in terms of validity, reliability, and validity konstruknya. Methods of data collection using questionnaires with respondents 200 elementary school students from class IV to class VI. Analysis using the statistical analysis program assisted SPPS 13 for Windows. Judging from the quality of the instruments developed realibitas looks pretty good instrument category at 0.881 and after the instrument items were eliminated from about 36 to 15 are also still in the good category is 0.813 . Based on the criteria of commonality factor extraction and rotation factors obtained four factors, number of factors extracted by the factor of as much as 4 percent of the cumulative variance is greater than $60 \%$ is $65.834 \%$. Judging from the validation performed factor by dividing the number of respondents into two groups of parts, and then performed a factor analysis on each hemisphere of the respondents. The results showed that the factor validation valid results, each still produce a 4 factor with almost equal distribution of items. This further strengthen that 4-dimensional factor in the scientific attitude for elementary school children on an instrument that has developed a strong enough konstruknya validity. The results of the development of scientific instruments already reflect the attitude and decent results are used to measure the scientific attitude of students in elementary school. 


\section{Pendahuluan}

Menumbuhkan sikap ilmiah sebagai salah satu tujuan dari pembelajaran sains masih kurang mendapat perhatian di sekolah dasar. Misalnya, kurang dibiasakannya siswa untuk bekerja secara ilmiah atau dengan metode ilmiah. Ardhana, dkk. (2004) mengemukakan bahwa mempelajari bahan ajar sains, siswa perlu dibantu dengan keterampilan ilmiah atau bekerja secara ilmiah karena akan mampu melatih sikap ilmiah. Santiasih (2013) menyatakan bahwa sikap ilmiah harus dipupuk dari sejak awal agar menjadikan mereka sebagai saintis yang sejati. Sikap ilmiah ini sangat membantu dalam mengubah prinsipnya dan menerima perbedaan jika ada sesuatu yang baru. Hasil penelitian Suastra (2004) juga mengungkapkan bahwa pembelajaran sains di SD laboratorium Undiksha sangat kurang melibatkan keterampilan proses sains seperti; keterampilan mengamati, mengelompokkan, mengukur, merumuskan hipotesis dan melakukan eksperimen, padahal potensi akademik anak-anak pada SD tersebut cukup baik. Pembelajaran yang berorientasi pada proses pembelajaran dan pengetahuan awal siswa, akan memberikan dampak yang positif dalam pembentukan sikap dan pemahaman siswa. Ausubel (1968) mengungkapkan bahwa pembelajaran akan bermakna jika siswa mampu mengaitkan informasi yang baru pada struktur kognitif yang telah ada. Pertanyaan-pertanyaan yang mampu memancing keingintahuan (curiosity) siswa, tentu akan membantu mengembangkan pemikirannya dalam berinteraksi dengan pengalaman atau pengetahuan yang baru. Sikap keingintahuan ini juga akan berkembang menjadi keinginan untuk memahami tentang konsep-konsep dan mengerti apa yang siswa kerjakan Siregar (2013).

Di beberapa negara maju, seperti British Colombia dan Canada pembelajaran sainsnya sudah menekankan pada penumbuhan sikap ilmiah, keterampilan proses sains, pengetahuan ilmiah, dan berpikir kritis, rasional dan kreatif (Bundu, 2006). Gega (1986) juga menyarankan pada empat sikap yang perlu dikembangkan yakni sikap ingin tahu (curiocity), penemuan (inventivenes), berpikir kritis (critical thinking), dan teguh akan pendirian (persistence). Keempat sikap ini yang merupakan indikator dari sikap ilmiah tidak dapat dipisahkan antara satu dengan yang lainnya karena saling melengkapi.

Pentingnya menumbuhan sikap ilmiah pada diri siswa sebagai salah satu dari tujuan mata pelajaran sains, tidak bisa dilepaskan dari karakterisitik sains itu sendiri. Martin (1997) mengemukakan beberapa karakteristik yang unik dari sains, yaitu; a) science rejects authority and authoritarianism, b) science is honest, c) science rejects supernatural explanations as primary explanations for observed phenomena, d) science is skeptical and rejects the notion that it is possible to attain absolute truth, e) science is parsimonious, $f$ ) science seeks consitency. Berdasarkan karakteristik sains yang unik tersebut, maka pembentukan atau menumbuhan sikap ilmiah mutlak di lakukan sejak dini. Dengan menumbuhkan sikap ilmiah sejak dini, sebenarnya membantu membentuk karakter anak didik menjadi lebih menghargai kejujuran, menolak hal-hal yang berbau tahayul atau tidak terlalu mudah percaya terhadap hal yang sifatnya mistis, menyukai kesederhanaan, dan konsisten atas keyakinannya.

Pengelompokan ciri-ciri sikap ilmiah oleh para ahli sangat bervariasi. Menurut Harlen (1992) mengelompokkan ciri-ciri sikap ilmiah menjadi empat ciri inti, meliputi; curisity, respect for evidence, willingness to change ideas, dan critical reflection. Neuman (1993) mengelompokkan tujuh ciri-ciri dari sikap ilmiah, yaitu: (1) curiosity, (2) honesty, (3) objectivity, (4) openness, (5) perseverance, (6) skepticism, (7) withholding judgment. Selanjutnya American Association for Advancement of Science (AAAS) menekankan pada empat sikap yang perlu untuk tingkat sekolah dasar, meliputi; (1) kejujuran (honesty), (2) keingintahuan (curiosity), (3) keterbukaan (open minded), (4) tidak terlalu mudah percaya (skepticism) (Bundu, 2006). Gega (1986) mengelompokkan sikap ilmiah menjadi menjadi empat sikap pokok yang harus dikembangkan dalam sains, yaitu: (1) curiosity, (2) inventiveness, (3) critical thinking, dan (4) persistence. Keempat sikap ini sebenarnya tidak dapat dipisahkan antara satu dengan yang lainnya karena saling melengkapi. Secara terperinci gambaran sikap tersebut dapat dilihat pada tabel berikut ini.

Tabel 1. Ciri-Ciri Sikap Ilmiah Siswa Sekolah Dasar

\begin{tabular}{|c|c|}
\hline Sikap Ilmiah & Ciri-ciri yang dapat diamati \\
\hline Curiosity & $\begin{array}{l}\text { - Menggunakan beberapa alat indra untuk menyelidiki } \\
\text { materi dan organisme } \\
\text { - Mengajukan pertanyaan tentang obyek dan peristiwa } \\
\text { - Memperlihatkan minat pada hasil percobaan }\end{array}$ \\
\hline Inventiveness & - Menggunakan alat tidak seperti biasanya dan dengan cara \\
\hline
\end{tabular}




\begin{tabular}{|c|c|}
\hline Critical Thinking & $\begin{array}{l}\text { yang konstruktif } \\
\text { - Menyarankan percobaan-percobaan yang baru } \\
\text { - } \text { Menguraikan konklusi baru dari pengamatan mereka } \\
\text { - Menggunakan bukti-bukti atau fakta-fakta untuk dasar } \\
\text { konklusi mereka } \\
\text { - Menunjukkan laporan yang berbeda dengan teman } \\
\text { kelasnya } \\
\text { Mampu merubah gagasan atau rencana ketika merespon } \\
\text { pada fakta-fakta yangada }\end{array}$ \\
\hline Persistence & $\begin{array}{l}\text { - Melanjutkan meneliti sesuatu sesudah sesuatu yang baru } \\
\text { telah hilang } \\
\text { - } \quad \text { Mengulangi percobaan meskipun berakibat kegagalan } \\
\text { - Melengkapi satu kegiatan meskipun teman sekelasnya } \\
\text { telah selesai lebih awal }\end{array}$ \\
\hline
\end{tabular}

(Adaptasi dari Gega, (1986) Science in Elementary Education)

Gambaran dan pengelompokan ciri-ciri dari sikap ilmiah anak khususnya anak di SD sebenarnya dapat diukur jika instrumen pengukurnya dibuat secara tepat. Untuk dapat menghasilkan instrumen yang valid dalam mengukur dimensi atau indikator-indikator yang diinginkan maka pengembangan instrumen harus dilakukan dengan prosedur yang tepat. Prosedur yang dimaksud adalah tahapan penyusunan instrument sikap yang mencerminkan domain sikap ilmiah secara komprehensif dengan cara; 1) menetapkan konstruk, yaitu membuat batasan mengenai variabel yang akan diukur, 2) menetapkan faktor-faktor untuk menemukan unsur-unsur yang ada pada sebuah konstruk, 3) menyusun butir-butir pernyataan (Santoso dalam Winarni, 2006). Namun, instrumen atau alat untuk mengukur sikap ilmiah yang sesuai dengan karakteristik siswa di Sekolah Dasar belum sepenuhnya ada atau dibuat dengan prosedur yang tepat. Kebanyakan peneliti khususnya peneliti pemula hanya mengandalkan validatas tes dan reliabelitas butir tes tanpa memperhatikan validitas konstruknya sehingga ketepatan dalam pengukuran menjadi bias.

Berdasarkan paparan di atas maka perlu dikembangkan instrumen yang dapat secara tepat mengukur sikap ilmiah siswa khususnya siswa SD. Dalam pengembangan instrumen ini, dimensi dari sikap ilmiah yang akan diukur adalah : 1) sikap ingin tahu, 2) sikap respek terhadap fakta atau bukti, 3) sikap berpikiran terbuka, 4) sikap berpikir kritis, 5) sikap ketekunan. Instrument sikap ilmiah ini diadopsi berdasarkan dimensi sikap ilmiah yang dikembangkan oleh Harlen (1992) dan Gega (1986).

\section{Metode}

Metode penelitian termasuk penelitan pengembangan yakni mengembangkan instrummen (kuesioner) untuk mengukur sikap ilmiah siswa SD melalui prosedur atau tahapan-tahapan yang ilmiah. Prosedur yang ditempuh agar instrument sikap mencerminkan domain sikap ilmiah secara komprehensif adalah dengan; 1) menetapkan konstruk, yaitu membuat batasan mengenai variabel yang akan diukur, 2) menetapkan factor-faktor yang mencoba menemukan unsur-unsur yang ada pada sebuah konstruk, 3) menyusun butir-butir pernyataan (Santoso dalam Winarni, 2006). Pengukuran sikap ilmiah siswa SD dapat di dasarkan pada pengelompokkan sikap sebagai dimensi sikap yang selanjutnya dikembangkan indikator-indikator sikap untuk setiap dimensi sehingga memudahkan untuk menyusun butir instrumen sikap ilmiah (Bundu, 2006).

Sampel atau subyek coba yang dilibatkan dalam ujicoba instrumen yang dikembangkan adalah siswa SD yang ada di kelas V dan VI di kecamatan Buleleng. Ada dua sekolah yang dilibatkan dalam kegiatan penelitan ini, yakni SD Lab Undiksha dan SD Nomor 1 Sari Mekar. Jumlah siswa yang dilibatkan dalam penelitian ini berjumlah 200 siswa.

Instrumen (kuesioner) sikap ilmiah yang telah dibuat selanjutnya dilakukan uji coba instrumen. Uji coba instrumen penelitian bertujuan untuk memastikan kelayakannya sebagai instrumen penelitian dilihat dari reliabilitas dan validitas. Tuckman (1999:444) mengemukakan bahwa reliabilitas minimal untuk instrumen sikap (attitude) adalah 0,5. Robinson (dalam Hair, dkk., 2006) menyatakan bahwa reliabilitas alpha Cronbach minimal 0,6 umumnya sudah diterima dalam penelitian ekploratori. Selanjutnya dilakukan analisis faktor guna menguji validitas konstruk dari instrumen sikap ilmiah.

Sebelum dilakukan analisis faktor, terlebih dahulu mengeliminasi item-item tes yang skor tes yang tidak berpola 1, 2, 3, 4, 5 melalui Method of Summated Ratings sehingga menghasilkan pola atau deretan 
angka interval tetap dari angka 1 sampai kepada angka 5. Untuk pernyataan favorabel angka tertinggi 5 diberikan pada jawaban sangat setuju dan angka terendah 1 diberikan bagi jawaban "sangat tidak setuju". Sebaliknya, pada jawaban yang tidak favorabel, jawaban "sangat setuju" mendapatkan angka terendah 1 dan jawaban "sangat tidak setuju" memperoleh angka tertinggi 5. Data dikumpulkan menggunaka kuesioner. Teknik analisis data menggunakan analisis statistik dengan berbantuan Program SPPS 13 for Windows.

\section{Hasil dan Pembahasan}

Instrumen sikap ilmiah yang telah dikembangkan diujicobakan pada pertengahan bulan Oktober 2013 pada dua SD yang ada di Kecamatan Buleleng, yaitu SD Lab Undiksha (4 kelas) dan SD Negeri 1 Sari Mekar (3 kelas). Total responden yang dilibatkan dalam penelitian ini berjumlah 200 siswa dengan total item sebanyak 36 . Reliabilitas instrumen sikap ilmiah adalah 0,881 yang telah memadai sebagai instrumen untuk mengukur skala sikap. Tuckman (1999:444) mengemukakan bahwa reliabilitas minimal untuk instrumen sikap (attitude) adalah 0,5. Robinson (dalam Hair, dkk., 2006) menyatakan bahwa reliabilitas alpha Cronbach minimal 0,6 umumnya sudah diterima dalam penelitian ekploratori. Selanjutnya dilakukan analisis faktor guna menguji validitas konstruk dari instrumen sikap ilmiah.

Sebelum dilakukan analisis faktor, terlebih dahulu mengeliminasi item-item tes yang skor tes yang tidak berpola 1, 2, 3, 4, 5 melalui Method of Summated Ratings sehingga menghasilkan pola atau deretan angka interval tetap dari angka 1 sampai kepada angka 5. Untuk pernyataan favorabel angka tertinggi 5 diberikan pada jawaban sangat setuju dan angka terendah 1 diberikan bagi jawaban "sangat tidak setuju". Sebaliknya, pada jawaban yang tidak favorabel, jawaban "sangat setuju" mendapatkan angka terendah 1 dan jawaban "sangat tidak setuju" memperoleh angka tertinggi 5. Berdasarkan uji Method of Summated Ratings diperoleh item-item yang tidak berpola atau deretan angka interval tidak berpola 1, 2, $3,4,5$ adalah item $5,13,18,20,23$, dan 33 . Item-item ini tidak menghasilkan nilai-nilai skala yang berjarak sama sehingga kurang layak digunakan untuk menguji sikap ilmiah. Item-item instrumen sikap ilmiah ini juga dieliminasi lagi dengan melihat item-item tes yang skor corrected item-total correlation kurang dari 0,40. Item-item tes yang skor corrected item-total correlation kurang dari 0,40 adalah item 5, $7,8,9,12,15,17,18,21,23,24,25,26,27,28,30$. Jumlah item soal yang tersisa setelah dieliminasi adalah 15 item. Item-tem yang terseleksi ini selanjutnya dilakukan analisis faktor.

Analisis faktor adalah metode statisitik yang digunakan untuk menentukan jumlah faktor (konstruk) yang terkandung dalam item angket, sekaligus mengeliminasi item-item yang tidak berkontribusi terhadap suatu faktor (Kirna, 2010). Ada tiga tahapan pokok yang dilakukan dalam analisis faktor, yaitu: (a) uji asumsi analisis faktor, (b) penentuan atau ekstraksi faktor, dan (c) validasi faktor. Uji asumsi dalam tahapan analisis faktor bertujuan untuk melihat kelayakan suatu instrumen atau mengelimianasi item-item yang tidak memenuhi kriteria. Berdasarkan uji asumsi dalam analisis faktor ditemukan uji korelasi inter item di atas 0,5, yang dapat dilihat dari anti image correlation matrix, sedangkan uji signifikansi Bartlett's test of sphericity dan Kaiser-Meyer-Olkin Measure of Sampling Adequacy (KMO) yaitu adanya korelasi yang cukup dari seluruh item (KMO $\geq 0,5)$. Uji asumsi instrumen sikap ilmiah memperlihatkan nilai $\mathrm{KMO}=0,813$ dan Bartlett's test of sphericity dengan sig $=0,00$ sehingga dapat dilakukan analisis faktor. Begitu pula dengan korelasi anti image, seluruh item yang berjumlah 15 item telah memenuhi kriteria di atas 0,5.

Pada tahap kedua adalah penentuan jumlah faktor yang terekstraksi. Ekstraksi faktor dilakukan dengan menggunakan metode Principal Component Analysis (PCA) dengan kriteria komunalitas minimal 0,5, eigenvalue minimal 1, dan factor loading minimal 0,5. Rotasi faktor menggunakan metode VARIMAX dilakukan untuk lebih memperjelas atau meningkatkan factor loading dari faktor yang terekstrak. Berdasarkan ekstraksi faktor dengan kriteria komunalitas dan rotasi faktor diperoleh 4 faktor, Jumlah faktor yang terekstrak sebanyak 4 faktor dengan persen kumulatif varian lebih besar dari $60 \%$ yaitu $65,834 \%$.

Tahap ketiga adalah validasi faktor. Validasi faktor dilakukan dengan membagi jumlah responden menjadi dua kelompok belahan, kemudian dilakukan analisis faktor terhadap masing-masing belahan responden. Hasil validasi faktor memperlihatkan bahwa hasil yang valid, masing-masing tetap menghasilkan 4 faktor dengan sebaran item hampir sama. Sebaran item pada masing-masing faktor (konstruk) dapat diringkaskan seperti di cantumkan pada tabel berikut ini. 
Tabel 2. Sebaran Item dalam Keempat Faktor (Konstruk)

\begin{tabular}{lll}
\hline Konstruk & Nama Konstruk & No item \\
\hline Konstruk 1 & Sikap ingin tahu & Item 1, 2, 3, 4, 20, 22, 31, dan 32 \\
Konstruk 2 & $\begin{array}{l}\text { Sikap berpikiran terbuka } \\
\text { Konstruk 3 }\end{array}$ & Item 6, 11, 29 \\
& $\begin{array}{l}\text { Sikap respek terhadap fakta } \\
\text { atau buti }\end{array}$ & Item 10, 19 \\
Konstruk 4 & Sikap kritis & Item 14, 16 \\
\hline
\end{tabular}

Hasil penelitian ini telah mengerucut pada empat dimensi sikap ilmiah yang paling sesuai untuk anak SD yaitu sikap ingin tahu, sikap berpikiran terbuka, sikap respek terhadap fakta atau bukti, dan sikap kritis. Sikap ingin tahu mendapatkan perolehan item yang paling banyak tidak tereliminasi yaitu dari sembilan item tereliminasi hanya satu. Hal ini menunjukkan bahwa sikap ingin tahu merupakan sikap dasar dari sikap ilmiah yang paling menonjol untuk anak SD. Bundu (2006) menyatakan bahwa sikap ingin tahu merupakan kategori umum yang dijumpai pada anak kecil melalui pertanyaan-pertanyaan yang spontan sesuai dengan dorongan kata hati sehingga mudah dirangsang untuk hal-hal yang baru.

Menurut Einstein (dalam Elshabrina, 2013) bahwa menjadi orang pintar bukan karena talent atau kecerdasan tinggi tapi bagaimana mengikuti rasa keingintahuan atau rasa penasaran yang muncul ketika melihat, mendengar, dan memikirkan sesuatu. Rasa ingin tahu akan mengantarkan seseorang untuk berinovasi dan berkreativitas untuk menemukan sesuatu yang baru.

\section{Simpulan dan Saran}

Berdasarkan hasil penelitian untuk pengembangan instrumen sikap ilmiah, maka dapat ditarik kesimpulan sebagai berikut.

1. Sikap ilmiah yang dikembangkan sudah memenuhi langkah-langkah ilmiah dalam pengembangan sebuah instrumen untuk penelitian. Adapun langkah-langkahnya meliputi; (1) reliabilitas minimal untuk instrumen sikap (attitude) adalah 0,5 atau 0,6 diterima dalam penelitian ekploratori, (2) mengeliminasi item-item tes yang skor tes yang tidak berpola 1, 2, 3, 4, 5 melalui Method of Summated Ratings sehingga menghasilkan pola atau deretan angka interval tetap dari angka 1 sampai kepada angka 5, (3) Selanjutnya dilakukan analisis faktor guna menguji validitas konstruk dari instrumen sikap ilmiah. Ada tiga tahapan pokok yang dilakukan dalam analisis faktor, yaitu: (a) uji asumsi analisis faktor, (b) penentuan atau ekstraksi faktor, dan (c) validasi faktor. Uji asumsi dalam tahapan analisis faktor bertujuan untuk melihat kelayakan suatu instrumen atau mengelimianasi item-item yang tidak memenuhi kriteria. Uji asumsi dalam analisis faktor diharapakan ditemukan uji korelasi inter item di atas 0,5, yang dapat dilihat dari anti image correlation matrix, sedangkan uji signifikansi Bartlett's test of sphericity dan Kaiser-Meyer-Olkin Measure of Sampling Adequacy (KMO) yaitu adanya korelasi yang cukup dari seluruh item (KMO $\geq 0,5)$. Uji asumsi instrumen sikap ilmiah diharapkan memiliki nilai KMO di atas 0,75 dan Bartlett's test of sphericity dengan sig $=0,00$ sehingga dapat dilakukan anlisis faktor. Begitu pula dengan korelasi anti image, seluruh item diharpkan telah memenuhi kriteria di atas 0,5, (4) penentuan jumlah faktor yang terekstraksi. Ekstraksi faktor dilakukan dengan menggunakan metode Principal Component Analysis (PCA) dengan kriteria komunalitas minimal 0,5, eigenvalue minimal 1, dan factor loading minimal 0,5. Rotasi faktor menggunakan metode VARIMAX dilakukan untuk lebih memperjelas atau meningkatkan factor loading dari faktor yang terekstrak.

2. Hasil ujicoba terhadap instrumen yang dikembangkan menghasilkan 15 item pernyataan sikap ilmiah untuk anak SD menghasilkan nilai KMO $=0,813$ dan Bartlett's test of sphericity dengan sig $=0,00$ sehingga dapat dilakukan anlisis faktor. Begitu pula dengan korelasi anti image, seluruh item yang berjumlah 15 item telah memenuhi kriteria di atas 0,5. Berdasarkan ekstraksi faktor dengan kriteria komunalitas dan rotasi faktor diperoleh 4 faktor, Jumlah faktor yang terekstrak sebanyak 4 faktor dengan persen kumulatif varian lebih besar dari 60\% yaitu 65,834\%. Selanjutnya dilihat dari validasi faktor dengan membagi jumlah responden menjadi dua kelompok belahan, kemudian dilakukan analisis faktor terhadap masing-masing belahan responden. Hasil validasi faktor memperlihatkan bahwa hasil yang valid, masing-masing tetap menghasilkan 4 faktor dengan sebaran item hampir sama.

Saran yang disampaikan berkenaan dengan pengembangan instrumen sikap ilmiah untuk anak SD dibagi menjadi tiga, yaitu : 1) saran Pemanfaatan: Pemanfaatan atau penggunaan instrumen sikap ilmiah yang telah dikembangkan ini diharapkan digunakan untuk kelas yang lebih tinggi yaitu dari kelas $\mathrm{V}$ ke atas. Hal ini tidak terlepas dari pemahaman bahwa pengembangan sikap ilmiah sangat lekat dengan teori perkembangan kognitif anak mengarah pada ranah operasional formal. Selain itu, instrumen yang dikembangan uji cobanya kebetulan hanya anak kelas V dan kelas VI saja, 2) saran desiminasi: Instrumen 
yang telah dikembangkan ini berdasarkan karakterisitik anak SD khususnya untuk anak di kelas V dan di kelas VI. Untuk selanjutnya diharapkan uji coba lebih luas lagi yakni melibatkan seluruh anak SD dari kelas 1 sampai di kelas 6 dengan melibatkan lebih dari dua kecamatan atau satu kabupaten saja. 3) saran pengembangan instrumen lebih lanjut: Saran pengembagan instrumen sikap ilmiah dapat dikembangkan pada anak taman kanak-kanak yang tentunya disesuaikan dengan karakteristik anak PAUD sehingga dapat dipetakan sikap ilmiah untuk anak usia dini sebesar apa saja dan apa saja indikator utamanya.

\section{Daftar Rujukan}

Ardhana, W., Kaluge, L., dan Purwanto. 2003. Pembelajaran inovatif untuk pemahaman dalam belajar matematika dan sains di SD, SLTP, dan di SMU. Laporan penelitian. Penelitian Hibah Pasca Angkatan I Tahun I. Direktorat Penelitian dan Pengabdian Masyarakat, Dirjen Dikti, Depdiknas.

Ardhana, W., Kaluge, L., dan Purwanto. 2004. Pembelajaran inovatif untuk pemahaman dalam belajar matematika dan sains di SD, SLTP, dan di SMU. Laporan penelitian. Penelitian Hibah Pasca Angkatan I Tahun II. Direktorat Penelitian dan Pengabdian Masyarakat, Dirjen Dikti, Depdiknas.

Bundu, P. 2006. Penilaian keterampilan proses dan sikap ilmiah dalam pembelajaran sains sekolah dasar. Jakarta: Departemen Pendidikan Nasional Direktorat Jenderal Pendidikan Tinggi Direktorat Ketenagaan

Dewi, N., Dantes, N., \& Sadia. I (2013). Pengaruh Model Pembelajaran Inkuiri Terbimbing Terhadap Sikap Ilmiah Dan Hasil Belajar IPA. Journal Program Pascasarjana Universitas Pendidikan Ganesha, Volume 3.

Edwards, A. L. 1969. Techniques of attitude scale construction. India:Vakils, Feffer and Simons Private Ltd

Elshabrina. 2013. Fakta unik dan menarik Albert Einstein. Cemerlang Publishing

Gega, P.C. 1986. Science in elementary education. New York: Jhon Wiley \& Son

Hair, J.F., Black, W.C., Babin, B.J., Anderson, R.E., \& Tatham, R.L. 2006. Multivariate Data Analysis (6th Ed.) Upper Saddle River: Pearson education Inc.

Harlen, W. 1992. The teaching of science. London: David Fulton Publisher

Kerlinger, F. N. 1986. Asas-asas penelitian behavioral. Terjemahan oleh Landung R. Simatupang. 1990. Yogyakarta: Gajah Mada University Press.

Maretasari,B.Subali, dan Hartono. 2012. Penerapan Model Pembelajaran Berbasis Laboratorium Untuk Meningkatkan Hasil Belajar dan Sikap Ilmiah Siswa. Unnes Physics Education Journal. Vol. 1.

Martin, D. J. 1997. Elementary scince methods a constructivist approach. Albany: Delmar Publisher

Murningsih, Ira Maya Tri, Mohammad Masykuri, Bakti Mulyani. 2016. Penerapan Model Pembelajaran Inkuiri Terbimbing untuk Meningkatkan Sikap Ilmiah dan Prestasi Belajar Kimia Siswa. Jurnal Inovasi Pendidikan IPA. Vol. 2, No. 2, Hal. 177-189.

Narmi, Nyoman, dan I Wayan. 2013. Pengaruh Model Pembelajaran Inkuiri Terbimbing Terhadap Sikap Ilmiah dan Hasil Belajar IPA. Jurnal Penelitian Pascasarjana Undiksha. Vol. 3, No. 1.

Rapi, N. K. 2005. Pengaruh model pembelajaran terhadap prestasi belajar fisika dan sikap ilmiah siswa (Eksperimen pada SMA Lab IKIP Negeri Singaraja). Tesis tidak diterbitkan. Singaraja: IKIP Singaraja

Salkind, N. J. 2006. Exploring research. Sixth edition. New Jersey: Pearson Education, Inc

Santiasih.N.L, A.A.I. Marhaeni, i. N.Tika. 2013. Pengaruh Model Pembelajaran Inkuiri Terbimbing Terhadap Sikap Ilmiah Dan Hasil Belajar IPA Siswa Kelas V SD No. 1 Kerobokan Kecamatan Kuta Utara Kabupaten Badung Tahun Pelajaran 2013/2014. Jurnal Pendidikan Dasar. Vol. 3, No. 1. 
Siregar, Suriani. 2013. Pengaruh Model Pembelajaran Inkuiri Berbasis Media Animasi Terhadap Pemahaman Konsep, Sikap Ilmiah Dan Assesmen Kinerja Siswa Pada Konsep Sintesis Protein. Jurnal EduBio Tropika. Vol. 1, Hal. 60-100.

Suastra, I W. 2009. Pembelajaran sains terkini: Mendekatkan siswa dengan lingkungan alamiah dan sosial budayanya. Singaraja: UNDIKSHA

Suciati, N.N.A, I.B.P. Arnyana, I G.A.N. Setiawan. 2014. Pengaruh Model Pembelajaran Siklus Belajar Hipotetikdeduktif Dengan Setting 7E Terhadap Hasil Belajar IPA Ditinjau Dari Sikap Ilmiah Siswa SMP. Jurnal Pendidikan Dasar. Vol. 4, No. 1. 